\title{
Sequential dehydration of the phosphate-sulfate association from Gura Dobrogei Cave, Dobrogea, Romania
}

\author{
Delia-Georgeta Dumitraş and Ştefan Marincea \\ Department of Mineralogy (INI), Geological Institute of Romania, 1 Caransebeş, \\ 0122271 Bucharest, Romania \\ Correspondence: Delia-Georgeta Dumitraş (d_deliaro@yahoo.com)
}

Received: 20 January 2021 - Revised: 17 May 2021 - Accepted: 25 May 2021 - Published: 29 June 2021

\begin{abstract}
A rich association of primary guano minerals, including taranakite, hydroxylapatite, brushite and gypsum with relicts of illite, kaolinite, alpha (low) quartz and calcite, was identified in the fossil bat guano deposit from Gura Dobrogei Cave, Dobrogea County, Romania. Gypsum and Ca phosphates developed preferentially on the carbonate bedrock or on fallen carbonate blocks in the guano mass, whereas taranakite was identified in the clay-rich, detritic sequences. The mineral species from the cave were characterized by optical methods, scanning electron microscopy, X-ray powder diffraction, Fourier-transform infrared and inductively coupled plasma-atomic emission spectrometry analysis. Chemically induced local dehydration of primary minerals, characterized by low temperatures (up to $100^{\circ} \mathrm{C}$ or even lower) and critically depending on exothermal reactions in the guano mass, prompted the formation of a secondary association, consisting of francoanellite, bassanite and monetite. Topotactic substitutions were observed in the cases of francoanellite on taranakite, bassanite on gypsum and monetite on brushite. In its turn, ardealite was partially replaced by monetite and bassanite. The sequential dehydration process seems driven by the degradation of organic matter by microbial action and also, presumably, by other exothermic reactions at local scale (e.g., oxidation of ammonia, allogenic pyrite or other organic compounds).
\end{abstract}

\section{Introduction}

The sequential dehydration affecting guano masses in dry caves exposed to air circulation was described or supposed by a number of authors (e.g., Hill and Forti, 1997; Karkanas et al., 2000; Onac and Vereş, 2003; Frost and Palmer, 2011; McFarlane and Lundberg, 2018; Audra et al., 2019, and references therein) in relation to the thermal or dehydration reactions in the guano mass. Chemically induced mineral genesis is responsible for dehydration of previously formed mineral species and was considered a complementary tool for completing the archeological record (e.g., Karkanas et al., 2000). In spite of the utility of the mineralogical observation for understanding the cave behavior or for archeological records, very clear relations between the various "primary" and "secondary" mineral species were, however, rarely depicted in the same cave. Local dehydration of the very stable authigenic mineral taranakite to francoanellite due to a local decrease in the water vapor pressure was, for exam- ple, described in the Măgurici Cave (Onac and Vereş, 2003) and expresses a path of the early diagenesis. In tropical caves where complete sequences of fossil bat guano minerals were subjected to desiccation, the microbial activity seems responsible of the breakdown by dehydration of variscite in berlinite or gibbsite (e.g., McFarlane and Lundberg, 2018).

Recent collecting in the fossil bat guano deposit in the cave from Gura Dobrogei (Romania) yielded several samples of great mineralogical interest. The aim of this work is to substantiate the data on the first described occurrence of monetite and the fifth occurrence of francoanellite in a Romanian cave and to offer new (mainly X-ray diffraction, XRD) data on a few more common cave minerals such as hydroxylapatite, brushite, ardealite, taranakite, gypsum and bassanite (e.g., Hill and Forti, 1997; McFarlane and Lundberg, 2018; Audra et al., 2019). The mineralogical approach proposed in this paper intends to clarify the early diagenesis of the fos- 


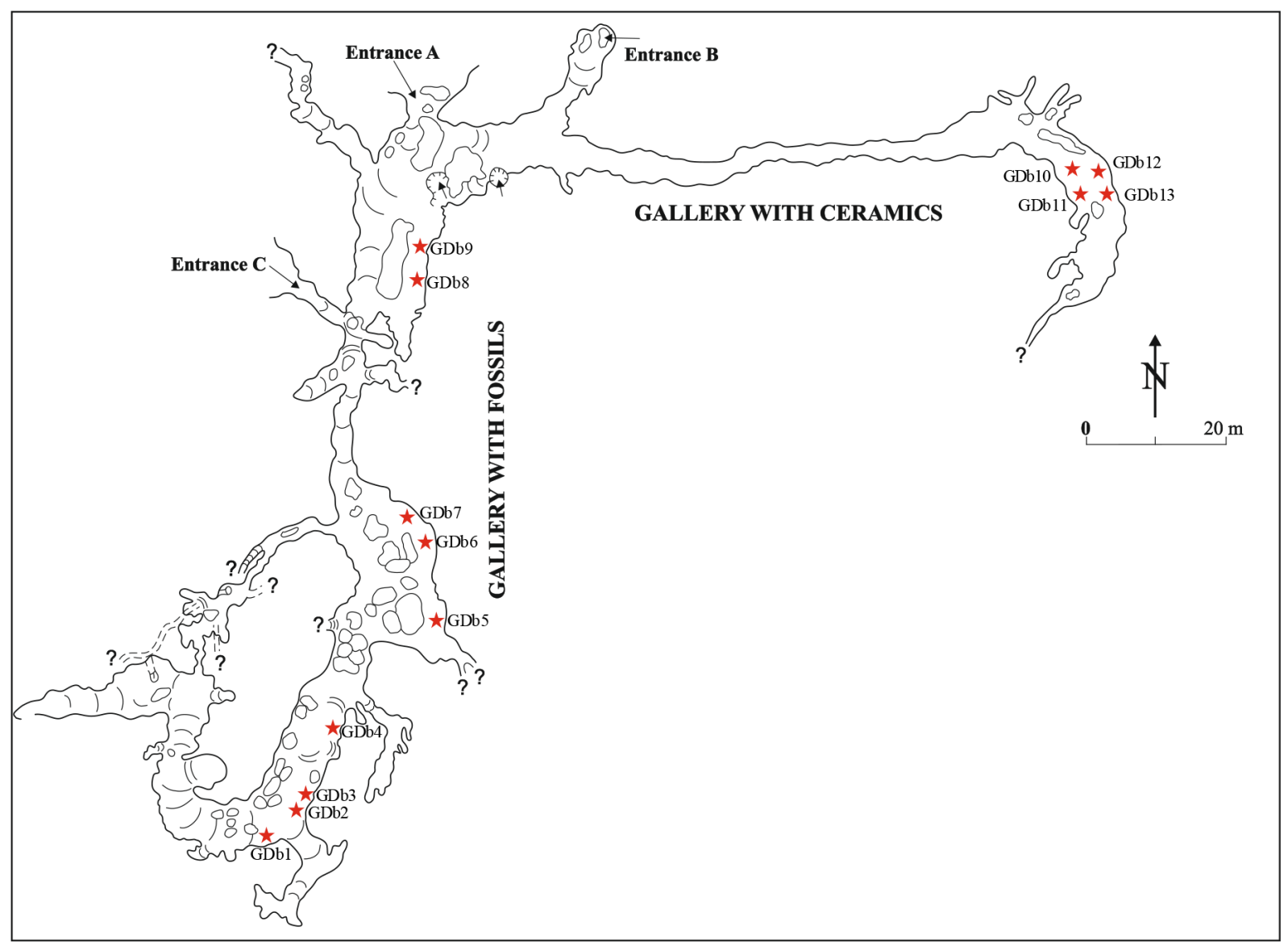

Figure 1. Plan view of the "the Bat Cave" (Peştera Liliecilor) from Gura Dobrogei, redrawn based on Dumitrescu et al. (1958). Symbols represent the following: $\mathrm{A}, \mathrm{B}$ and $\mathrm{C}$ - entrances; $\star$ - access ways to secondary passages and short galleries.

sil guano in one of the richest phosphate-sulfate associations from a Romanian Cave.

\section{Geological setting}

The cave from Gura Dobrogei is located in Constanţa County, Dobrogea Region, Romania, about $3 \mathrm{~km}$ to the west from the homonymous locality and about $42 \mathrm{~km}$ northnorthwest from Constanţa, the major city in the area. The GPS coordinates of the main entrance ( $C$ in Fig. 1) are $44.467^{\circ} \mathrm{N}$ and $28.482^{\circ} \mathrm{E}$, and its altitude is $106.7 \mathrm{~m}$. The cave is also known as "the Bat Cave" (Peştera Liliecilor) from Gura Dobrogei.

The cave represents an upper (fossil) level of a karst system that developed on Visterna Brook, a tributary of Casimcea River, which in turn ends in Lake Taşaul, a former lagoon of the Black Sea. The cave has the main entrance on the right slope of the Visterna Brook and is developed in Upper Jurassic limestones of the Casimcea Syncline, in fact biostrome and bioherm limestones with sponges and microbialites (Bărbulescu, 1999). The altitude of the main entrance is about $50 \mathrm{~m}$ from the thalweg of the brook. A detailed description of the cave and of its topography was given by Dumitrescu et al. (1958), from which was taken the plan view in Fig. 1.

The length of the main parts of the cave is about $480 \mathrm{~m}$ (Dumitrescu et al., 1958), but, after the investigation of the short and narrow divergent passages, the total length was $1365.8 \mathrm{~m}$ (https://www.speologie.org/ pestera-liliecilor-de-la-gura-dobrogei, last access: $1 \mathrm{Au}-$ gust 2020). A rich deposit of fossil bat guano is hosted in two of the galleries of the cave: the east-west oriented Gallery with Ceramics (or Circassian Gallery) and the north-south oriented Gallery with Fossils. The fossil guano deposit covers integrally the floor of the Gallery with Fossils, whereas the Circassian Gallery contains such a deposit only in its terminal part (Dumitrescu et al., 1958).

The humidity of the cave is about $80 \%$, and the mean temperature is $12.5^{\circ} \mathrm{C}$. The three entrances of the cave favor the formation of strong air currents that locally reduce the high humidity and dry the surface of the guano deposits. Some small colonies of insectivorous bats, pertaining to Mediterranean species Rhinolophus mehelyi and Myotis mystacinus, locally produce fresh guano accumulations. These recent accumulations increase the local temperature at the surface by 
about $4{ }^{\circ} \mathrm{C}$ and also increase the content of moisture (28 to $33 \mathrm{vol} \%)$ and the acidity $(\mathrm{pH}=5.19-5.96)$. In the fossil guano deposits, $\mathrm{pH}$ inversely correlates with depth and with moisture content. Moisture content measured for the fossil guano samples fluctuates between $\sim 14$ and 22 vol \%, whereas $\mathrm{pH}$ values range from 6.18 to 7.15 .

\section{Analytical procedures}

The samples were taken from both the Circassian Gallery and Gallery with Fossils, from both the surface and the mass of guano deposits, and from their contact with the wall rock and floor. The location of the sampling points is given in Fig. 1. In order to avoid supplementary dehydration, samples were stored after collection in sealed plastic bags at room temperature.

Observations of the crystal morphologies were conducted using a JEOL JSM-840 scanning electron microscope (SEM) manufactured by JEOL Ltd. (Tokyo, Japan). Acquisitions of energy-dispersive spectra (EDS) were made using a Tracor Northern TN-2000 system for $100 \mathrm{~s}$ (live time) with an accelerating voltage of $10 \mathrm{kV}$ and a beam current of $10 \mathrm{nA}$. $\mathrm{X}$-ray spectra were collected and processed with the PGT semiquantitative software. Full ZAF corrections (for atomic number, absorption and fluorescence effects) were applied to the raw X-ray data, but the results were of very poor quality due to the heating under the beam of the samples. The beam sensitivity due to dehydration prevented the acquisition of good-quality SEM pictures at high magnification.

Bulk methods of analysis were preferred, consequently. Samples were prepared for analysis by hand-picking bunches of crystals, and carefully verified for purity by X-ray powder diffraction. The purified separate was crushed, lightly ground in acetone and then dried, rapidly etched with cold $0.01 \mathrm{~N}$ $\left(0.6 \mathrm{~g} \mathrm{~L}^{-1}\right)$ acetic acid, abundantly washed with acetone, and again air dried. No supplementary hydration was observed after this treatment, which fully removes organic matter and moonmilk from the sample.

Chemical compositions were verified by inductively coupled plasma-atomic emission spectrometry (ICP-AES) after selective dissolution. The analyses were carried out using a Jobin-Yvon 138 Ultrace spectrometer (HORIBA Scientific, Villeneuve-d'Ascq, France). For the ICP-AES analysis, aliquots of $0.2 \mathrm{~g}$ of finely pulverized sample were dissolved in $6 \mathrm{~mL}$ of concentrated $(65 \%) \mathrm{HCl}$, boiled until drying, removed with $20 \mathrm{~mL}$ of $\mathrm{HCl} 2 M$ and then analyzed.

The X-ray powder diffraction study was carried out using an automated Siemens D-5000 Krystalloflex diffractometer (Siemens, Ettlingen, Germany), fitted with graphite monochromator and employing $\mathrm{Cu} \mathrm{K}_{\alpha}$ radiation $(\lambda=$ $1.54056 \AA$ ). The instrument was operated at $40 \mathrm{kV}$ and $30 \mathrm{~mA}$. A $0.6 \mathrm{~mm}$ receiving slit was used, in a slit system of $1-0.1-1$. The scan speed was $4^{\circ} \mathrm{s}^{-1}$, the step size was fixed at $0.01^{\circ} 2 \theta$, and data were collected from 4 to $110^{\circ}$
2 $\theta$. Synthetic silicon (NBS 640b) was used for calibration and as internal standard. Supplementary XRD analyses were performed on a Phillips PW 3710 automated diffractometer (Philips, Eindhoven, Netherlands) using Mn-filtered Fe $K \alpha$ radiation $(\lambda=1.93735 \AA)$. The apparatus was operated under a voltage of $40 \mathrm{kV}$, with a beam current of $30 \mathrm{~mA}$, using a step size of $0.04^{\circ} 2 \theta$, a counting time of $1 \mathrm{~s}$ per step and a scanning range of 5 to $90^{\circ} 2 \theta$. The slit system was the same for the other diffractometer used. Synthetic fluorite, with $a=5.4638(3) \AA$, was used as the internal standard. A complete set of data issued from up to 50 diffraction patterns is available upon request from the first author, whereas part of the X-ray powder data is given in the Supplement (Tables S1, S2). The unit cell parameters were refined from X-ray powder data by the least-squares program CELREF (Appleman and Evans, 1973) as modified for microcomputer use by Benoit (1987).

The infrared absorption spectrum of a francoanellite sample, the sole sample pure enough to be analyzed by this method, was recorded by a Fourier-transform Thermo Nicolet Nexus spectrometer (Thermo Fisher Scientific, Madison, United States), in the frequency range $400-4000 \mathrm{~cm}^{-1}$, using a standard pressed-disk technique after embedding $1 \mathrm{mg}$ of mechanically ground sample in $200 \mathrm{mg}$ of dry $\mathrm{KBr}$ and compacting under $2500 \mathrm{~N} \mathrm{~cm}^{-2}$ pressure.

Indices of refraction were measured without heating using calibrated oils, a spindle stage and a classical JENAPOL-U microscope (Carl Zeiss, Jena, Germany).

\section{Mineralogy of the guano deposit}

\subsection{Primary (authigenic) minerals}

\subsubsection{Hydroxylapatite}

Hydroxylapatite generally occurs as ochre to orange crusts lining the contact between the guano mass and the walls, as infillings of some veins traversing the guano mass, or as massive masses developed on the calcareous boulders contained by the guano. The crusts range up to $1 \mathrm{~cm}$ in thickness. The SEM examination shows that they are composed of thick beds of crystalline aggregates whose morphology varies from randomly deposited laths to post-colloidal, rosette-like deposits. Intergrown laths with a hexagonal habit generally compose the aggregates. Individual crystals are platy on (0001) and typically smaller than $10 \mu \mathrm{m}$ across; rarely they attain $20 \mu \mathrm{m}$. A typical aggregate of hydroxylapatite is shown in Fig. 2.

The indices of refraction of a representative sample (GDb $5 \mathrm{~B})$, measured in immersion at $25^{\circ} \mathrm{C}$, are $\omega=1.647$ (1) and $\varepsilon=1.640(1)$, which are identical to those given by Lehr et al. (1967) for the stoichiometric hydroxylapatite.

Unit cell parameters of hydroxylapatite are given in Table 1 . 
Table 1. Crystallographic parameters of selected guano minerals in the Gura Dobrogei Cave.

\begin{tabular}{|c|c|c|c|c|c|c|c|c|c|c|c|c|}
\hline $\begin{array}{l}\text { Mineral } \\
\text { species }\end{array}$ & $\begin{array}{l}\text { Space } \\
\text { group }\end{array}$ & Sample & $a(\AA)$ & $b(\AA)$ & $c(\AA)$ & $\alpha\left(^{\circ}\right)$ & $\beta\left(^{\circ}\right)$ & $\gamma\left({ }^{\circ}\right)$ & $V\left(\AA^{3}\right)$ & $n^{1}$ & $N^{2}$ & $2 \theta^{3}$ \\
\hline Hydroxylapatite & $P 6_{3} / m$ & GDb 5 B & $9.427(3)$ & - & $6.856(4)$ & - & - & - & $527.7(4)$ & 7 & 38 & $10-80$ \\
\hline Hydroxylapatite & $P 6_{3} / m$ & GDb $7 \mathrm{~A}$ & $9.429(3)$ & - & $6.864(3)$ & - & - & - & $528.6(4)$ & 8 & 58 & $10-80$ \\
\hline Hydroxylapatite & $P 6_{3} / m$ & GDb $10 \mathrm{~B}$ & $9.428(4)$ & - & $6.877(5)$ & - & - & - & $529.3(4)$ & 6 & 42 & $10-80$ \\
\hline Brushite & $I a$ & GDb 3 A & $5.809(1)$ & $15.186(3)$ & $6.242(2)$ & - & $116.35(1)$ & - & $516.6(2)$ & 8 & 53 & $5-90$ \\
\hline Brushite & $I a$ & GDb $3 \mathrm{~B}$ & $5.815(2)$ & $15.181(5)$ & $6.241(2)$ & - & $116.29(2)$ & - & $504.5(3)$ & 9 & 62 & $5-90$ \\
\hline Brushite & $I a$ & GDb $5 \mathrm{~A}$ & $5.809(2)$ & $15.182(5)$ & $6.240(2)$ & - & $116.41(2)$ & - & $526.8(3)$ & 7 & 88 & $5-90$ \\
\hline Brushite & $I a$ & $\mathrm{GDb} 5$ & 840 & $15.192(7)$ & 6.252 & - & $116.49(3)$ & - & 542 & 5 & 35 & $5-90$ \\
\hline Brushite & $I a$ & GDb 7 A & $5.811(3)$ & $15.202(6)$ & $6.236(3)$ & - & $116.36(2)$ & - & $518.7(3)$ & 9 & 67 & $5-90$ \\
\hline Brushite & $I a$ & $\mathrm{GDb} 12 \mathrm{~A}$ & $5.840(4)$ & $15.204(8)$ & $6.259(3)$ & - & $116.29(3)$ & - & $508.9(4)$ & 5 & 55 & $5-90$ \\
\hline Brushite & $I a$ & $\mathrm{GDb} 13 \mathrm{~A}$ & $5.813(3)$ & $15.200(9)$ & $6.242(3)$ & - & $116.47(3)$ & - & $536.6(4)$ & 10 & 58 & $5-90$ \\
\hline Gypsum & $I 2 / a$ & GDb 7 B & $5.717(3)$ & $15.198(4)$ & $6.517(1)$ & - & $118.27(2)$ & - & $498.8(3)$ & 6 & 43 & $10-85$ \\
\hline Gypsum & $I 2 / a$ & GDb $12 \mathrm{~B}$ & $5.669(2)$ & $15.193(4)$ & $6.503(2)$ & - & $118.37(2)$ & - & $492.9(2)$ & 9 & 80 & $10-85$ \\
\hline Ardealite & $C c$ & GDb $3 \mathrm{~A}$ & $5.724(3)$ & $30.977(13)$ & $6.261(4)$ & - & $117.25(3)$ & - & $948.5(6)$ & 6 & 84 & $5-75$ \\
\hline Ardealite & $C c$ & GDb $5 \mathrm{~A}$ & $5.717(2)$ & $30.957(10)$ & $6.254(2)$ & - & $117.11(2)$ & - & $985.3(4)$ & 5 & 99 & $5-75$ \\
\hline Bassanite & $I 2$ & GDb 3 A & $12.046(9)$ & 6.921(8) & $12.749(9)$ & - & $90.25(6)$ & - & $1038.5(7)$ & 5 & 32 & $5-90$ \\
\hline Bassanite & $I 2$ & $\mathrm{GDb} 12 \mathrm{~B}$ & $12.099(3)$ & $6.919(1)$ & $12.689(4)$ & - & $90.46(2)$ & - & $1062.2(3)$ & 6 & 35 & $5-90$ \\
\hline Taranakite & $R \overline{3} c$ & GDb $6 \mathrm{~A}$ & 8.694(2) & - & 94.98(4) & - & - & - & $6218.2(33)$ & 7 & 92 & $5-66$ \\
\hline Francoanellite & $R \overline{3} c$ & $\mathrm{GDb} 11 \mathrm{~A}$ & $8.695(2)$ & - & $82.44(2)$ & - & - & - & $5396.9(19)$ & 9 & 93 & $5-70$ \\
\hline Francoanellite & $R \overline{3} c$ & $\mathrm{GDb} 11 \mathrm{~B}$ & $8.696(1)$ & - & $82.26(3)$ & - & - & - & 5388.1(18) & 6 & 62 & $5-90$ \\
\hline Monetite & $P \overline{1}$ & GDb $3 \mathrm{~A}$ & $6.912(4)$ & $6.680(5)$ & $6.963(4)$ & $96.35(8)$ & $103.90(3)$ & $88.73(7)$ & $311.8(3)$ & 10 & 72 & $10-75$ \\
\hline Monetite & $P \overline{1}$ & GDb $5 \mathrm{~A}$ & $6.680(5)$ & $6.667(9)$ & $6.919(7)$ & $94.17(3)$ & $104.06(6)$ & $87.25(8)$ & $307.3(8)$ & 7 & 98 & $10-75$ \\
\hline Monetite & $P \overline{1}$ & GDb $13 \mathrm{~A}$ & $6.963(4)$ & $6.666(9)$ & $6.952(4)$ & $95.21(4)$ & $102.05(4)$ & $89.17(5)$ & $310.5(5)$ & 5 & 66 & $10-75$ \\
\hline
\end{tabular}

${ }^{1}$ Number of cycles of refinement; ${ }^{2}$ number of reflections used for refinement; ${ }^{3}$ range of $2 \theta$ angles used in collecting the reflections.

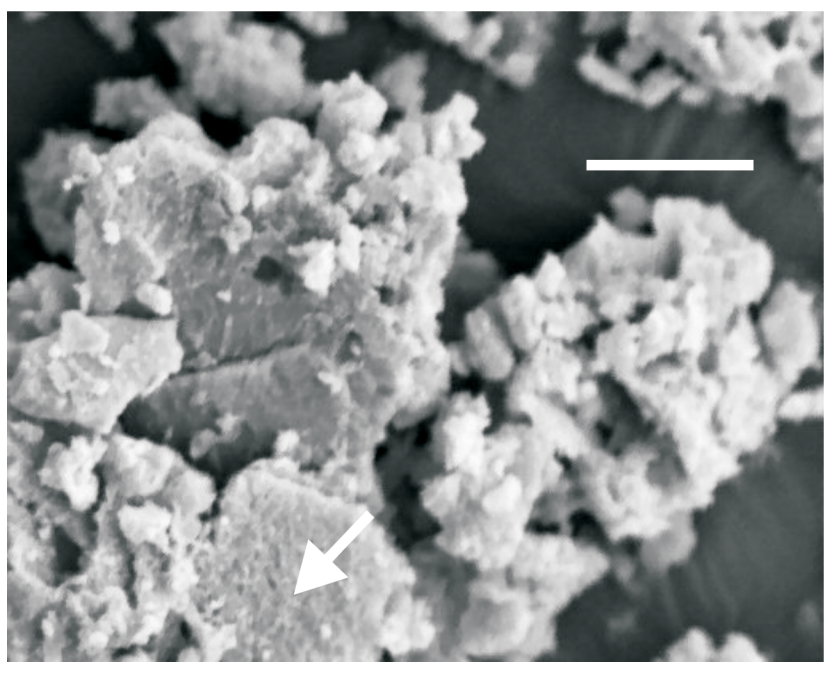

Figure 2. SEM image showing a typical aggregate of hydroxylapatite from Gura Dobrogei. The arrow indicates a well-shaped crystal in the bottom-central part of the photograph. The scale bar (top) represents $10 \mu \mathrm{m}$.

Diffraction lines are slightly broadened by the fine size of the crystallites in spite of a relatively good crystallinity. The indices of crystallinity, calculated following the method proposed by Simpson (1964), differentiate, at Gura Dobrogei, two types of hydroxylapatite as follows:

- A first type, whose representative sample is GDb 5 $\mathrm{B}$, is generally deposited directly on a carbonate sup- port. The crystallinity index is high (I.C. $=0.324$ for the referred sample), indicative of a poor crystallinity. Particularizing for the unit cell parameters in Table 1, they seem indicative of a carbonate-bearing hydroxylapatite since the $c$ parameter is smaller and the $a$ cell parameter is greater than those quoted by various authors for carbonate-free hydroxylapatite (e.g., $a=$ 9.4176(5) $\AA$ and $c=6.8814(5) \AA$ according to Elliott, 1994; $a=9.423(2) \AA$ and $c=6.882(3) \AA$ according to Bigi et al., 1996; $a=9.421(2) \AA$ and $c=6.882(3) \AA$ according to Brunet et al., 1999; $a=9.4244(2) \AA$ and $c=6.8854(2) \AA$ according to Morgan et al., 2000; and $a=9.4302$ (5) $\AA$ and $c=6.8911(2) \AA$ according to Dorozhkin and Epple, 2002).

- A second type, whose representative samples are GDb7 $\mathrm{A}$ and $\mathrm{GDb} 10 \mathrm{~B}$, occurs in crusts differentiated in the guano mass. The crystallinity index is lower (I.C. $=0.077$ and I.C. $=0.083$, respectively, for the quoted samples), indicative of a high crystallinity. The unit cell parameters of the two samples of the second type maintain the characteristics of a carbonate-bearing hydroxylapatite.

\subsubsection{Gypsum}

Gypsum is one of the most common sulfates in the bat guano deposits from the caves (Hill and Forti, 1997). At Gura Dobrogei, the mineral occurs as centimeter-sized, white nodules or earthy masses in the guano layer and generally forms parallel aggregates of minute bladed crystals up to $100 \mu \mathrm{m}$ in 
length. The individual crystals are thin, flattened on $\{010\}$ and elongated toward [001]. Stacking aggregates of crystals grown subparallel or parallel to (010) are common. The unit cell parameters determined for two representative samples by least-squares refinement, based on the best resolved X-ray powder diffraction lines, are given in Table 1 . The refinements were carried out accepting the monoclinic symmetry, space group $I 2 / c$, of the mineral (Cole and Lancucki, 1974).

\subsubsection{Brushite}

Brushite commonly occurs as very fine-grained snow-white coatings up to $1 \mathrm{~cm}$ thick covering hydroxylapatite, as irregular lining of hydroxylapatite bunches of crystals or as partial fillings of veinlets or cracks affecting the hydroxylapatite mass. The mineral also occurs as spherules up to $1 \mathrm{~cm}$ across enclosed by the detrital-rich sequences within the guano mass near calcite boulders. The SEM study shows that, in all cases, randomly oriented clusters of crystals with individuals reaching up to $15 \mu \mathrm{m}$ in length (probably on [101] or [102] as for the synthetic crystals obtained by Abbona et al., 1993) compose the brushite aggregates. The most typical crystals are up to $10 \mu \mathrm{m}$ long, $5 \mu \mathrm{m}$ wide and $1 \mu \mathrm{m}$ thick.

The unit cell parameters of brushite, calculated as the average of the seven sets of values in Table 1 , are $a=$ 5.820(14) $\AA, b=15.192(10) \AA, c=6.245(8) \AA$ and $\beta=$ $116.38(8)^{\circ}$, where the errors in the brackets correspond to the standard deviations of the mean $(2 \sigma)$ for each set of data. The obtained values are slightly larger than those given for the synthetic brushite by Curry and Jones (1971) (i.e., $a=5.812(2) \AA, b=15.180(3) \AA, c=6.239(2) \AA$ and $\beta=$ $\left.116.42(2)^{\circ}\right)$ but are in good agreement with those calculated by us for a sample of natural brushite from Angolo Incantato Cave, whose diffraction pattern was published by Balenzano et al. (1974): $a=5.818(1) \AA, b=15.194(3) \AA$, $c=6.247(2) \AA$ and $\beta=116.42(1)^{\circ}$.

\subsubsection{Ardealite}

Ardealite occurs as earthy, damp, white-yellow or off-white aggregates, directly deposited on hydroxylapatite crusts or as nests and small veins in the brushite-hydroxylapatite masses. These aggregates are composed of very fine, tabular sprays of crystals of maximum $20 \mu \mathrm{m}$ in length and up to $1 \mu \mathrm{m}$ wide. These compact radial groups are generally built up of thin blades or individual crystals with the $c^{*}$ axis pointing outwards from the center. Stacking aggregates of crystals are also common.

As already mentioned by Dumitraş (2017), the X-ray powder diffraction pattern of ardealite is similar to, although distinguishable from, that of synthetic $\mathrm{Ca}_{2}\left(\mathrm{HPO}_{4}\right)\left(\mathrm{SO}_{4}\right) \cdot 4 \mathrm{H}_{2} \mathrm{O}$ (Sakae et al., 1978). In all cases, at least four medium to strong lines in all the patterns, centered at about 4.30, 4.10, 3.15 and $2.95 \AA$, could not be indexed or related to any known impurity if we accept the crystallization of ardealite

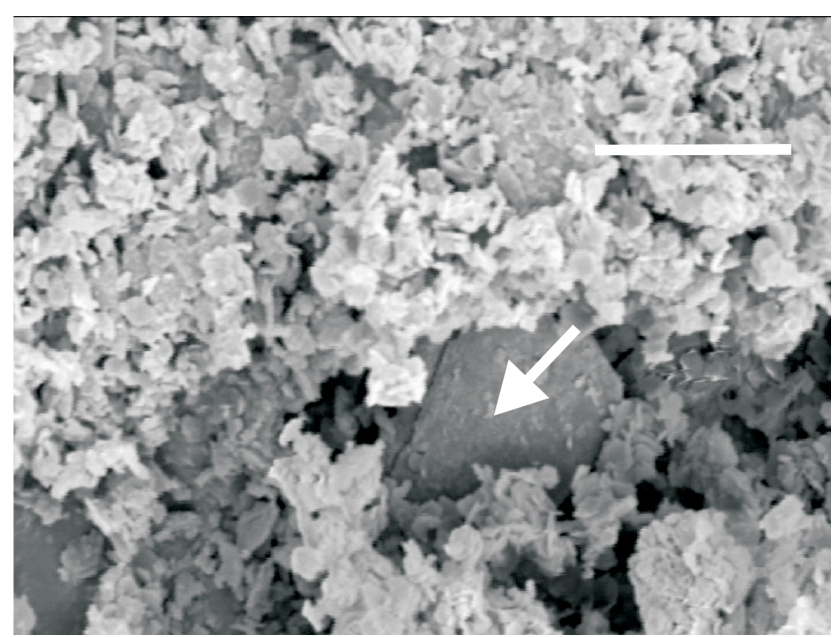

Figure 3. SEM image of a taranakite aggregate overgrown by francoanellite. The arrow indicates a roughly hexagonal crystal. The scale bar (top) represents $10 \mu \mathrm{m}$.

in the centrosymmetric group $C c$ (Sakae et al., 1978). The most representative X-ray diffraction pattern obtained for an ardealite sample from Gura Dobrogei was, however, indexed based on the $C c$ cell proposed by Sakae et al. (1978). The unit cell parameters (Table 1) are in good agreement with those reported by Sakae et al. (1978) for the synthetic $\mathrm{Ca}_{2}\left(\mathrm{HPO}_{4}\right)\left(\mathrm{SO}_{4}\right) \cdot 4 \mathrm{H}_{2} \mathrm{O}(a=5.721(5), b=30.992(5), c=$ $6.250(4) \AA$ and $\left.\beta=117.26(6)^{\circ}\right)$ and also with those refined for natural samples in the $C c$ hypothesis of symmetry by various authors (Dumitraş, 2017, and referred to works).

\subsubsection{Taranakite}

Taranakite generally forms chalky monomineralic nodular aggregates up to $1 \mathrm{~cm}$ across in the cave sediments resembling terra rossa. It also may form very fine powdery coatings on fractures affecting the sediment. In both cases taranakite masses are soft, earthy-looking and porous. The nodules are generally sharply defined because of the difference in color between them and the terra rossa mass. A transition zone where taranakite closely associates with $\alpha$-quartz may locally be observed and occurs as coatings of powdery monomineralic taranakite nodules. Outside this zone, the unaffected sediment still contains illite and kaolinite. SEM microphotographs of taranakite aggregates (Fig. 3) show that they are composed of bunches of parallel slender laths or thin, roughly hexagonal platy crystals. Frequently, the crystals, which are only loosely interlocked within the masses, are poorly developed or broken. Individual crystals are flattened on (0001), averaging $5 \mu \mathrm{m}$ in size; they may exceptionally reach $15 \mu \mathrm{m}$ across and $2 \mu \mathrm{m}$ thick.

The unit cell parameters refined for a representative sample of taranakite from Gura Dobrogei are given in Table 1. The calculated $a: c$ ratio (i.e., $0.0915: 1$ ), as well as the cell 
dimensions, fits well with the values reported by Marincea and Dumitraş (2003) for the synthetic potassium taranakite $\left[\mathrm{K}_{3} \mathrm{Al}_{5}\left(\mathrm{HPO}_{4}\right)_{6}\left(\mathrm{PO}_{4}\right)_{2} \cdot 18 \mathrm{H}_{2} \mathrm{O}\right]$. The unit cell parameters of taranakite from Gura Dobrogei are smaller than the values refined for the synthetic $\mathrm{K}_{3} \mathrm{Al}_{5}\left(\mathrm{HPO}_{4}\right)_{6}\left(\mathrm{PO}_{4}\right)_{2} \cdot 18 \mathrm{H}_{2} \mathrm{O}$ $(a=8.7025(11) \AA, c=95.05(1) \AA$ from X-ray powder data) but compare favorably with the values refined from neutrondiffraction data by Dick et al. (1998): $a=8.6882(3) \AA, c=$ 94.98(2) А.

\subsection{Secondary minerals resulting from dehydration}

\subsubsection{Bassanite}

As well as in the cave from Cioclovina (Dumitrass et al., 2004), bassanite occurs as pseudomorphs after gypsum, whose perfect cleavage parallel to $\{010\}$ is always observable. No textural signs of the reverse reaction, of bassanite hydration to gypsum (e.g., Van Driesche et al., 2012) were observed. The gypsum + bassanite association occurs as decimeter-sized, white nodules of earthy or chalky appearance included by the guano deposits. No fluorescence has been observed for these nodules under either short-wave $(254 \mathrm{~nm})$ or long-wave $(366 \mathrm{~nm})$ ultraviolet radiation. The SEM study shows that bassanite occurs as clustered acicular crystals that parallel the [001] axis of gypsum. They currently show parallel growth along the longest axis. Crystals are on the order of no more than $5 \mu \mathrm{m}$ in length and often much less than this. Indices of refraction measured in yellow light $(\lambda=$ $589 \mathrm{~nm}$ ) as maximum and minimum values, respectively, by immersion of aggregates of platy crystals in calibrated liquids are $n_{\min }=\alpha=1.555(4)$ and $n_{\max }=\gamma=1.580(3)$. Accepting that the mean optical angle $\left(+2 V_{x}=77.5^{\circ}\right)$ given by Palache et al. (1961) for the mineral is closely approximated in the case of our samples, it is possible to calculate a $\beta$ value of 1.570, which is larger than that given for bassanite by Palache et al. (1961): $\beta=1.560$.

The unit cell parameters in Table 1 are in reasonable agreement with those refined for the stoichiometric calcium sulfate hemihydrate by Ballirano et al. (2001): $a=12.0350(5) \AA$, $b=6.9294(3) \AA, c=12.6705(4) \AA$ and $\beta=90.266(3)^{\circ}$.

\subsubsection{Francoanellite}

In spite of the quite important number of francoanellite occurrences in bat guano deposits from Romanian caves (i.e., Onac and Vereş, 2003; Marincea et al., 2004; Giurgiu and Tămaş, 2013), there is a general lack of data on this rather rare mineral species. At Gura Dobrogei, francoanellite was identified as cream-white nodules of earthy appearance, clearly distinguishable in the terra rossa mass. In most of the samples, the mineral associates with taranakite, illite $2 M 1$ and alpha quartz. The SEM study shows that francoanellite occurs in these cases as topotactic replacements of taranakite (Fig. 3). The noticeable exception was encountered in the case of Sample GDb 11 A, in which all the diffraction reflections can be attributed to francoanellite. In both cases, the individual crystals are platy after (0001) and have hexagonal habit, with developments up to $10 \mu \mathrm{m}$ across and $1 \mu \mathrm{m}$ thick.

The indices of refraction were measured on stacks of platy subparallel crystals with hexagonal contour as maximum and minimum values, respectively. The average values obtained in yellow light $(\lambda=589 \mathrm{~nm})$ are $n_{\max }=\omega=1.515(3)$ and $n_{\min }=\varepsilon=1.509(2)$. The mean index of refraction that may be deduced from these values, applying the relation proposed by Mandarino (1976) for uniaxial crystalline compounds, is $\bar{n}=(2 \varepsilon+\omega) / 3=1.511$.

The average of five density measurements by the sinkfloat method, using a mixture of bromoform and toluene as immersion liquid, is $D_{\mathrm{m}}=2.265(3) \mathrm{g} \mathrm{cm}^{-3}$. The calculated density for $Z=6$ (Dick and Zeiske, 1998), and considering a unit cell volume taken as the average of the two values in Table 1 , is $D_{x}=2.268 \mathrm{~g} \mathrm{~cm}^{-3}$, which is practically identical to the measured value in the limit of errors. Note that all the measured values of density reported for francoanellite by previous authors (e.g., Balenzano et al., 1976) are slightly smaller than those calculated, which may be connected to the unusually high specific surface of the mineral and to its layered structure (Dick and Zeiske, 1998). Both values of density are smaller than that calculated for the synthetic $\mathrm{K}_{3} \mathrm{Al}_{5}\left(\mathrm{HPO}_{4}\right)_{6}\left(\mathrm{PO}_{4}\right)_{2} \cdot 12 \mathrm{H}_{2} \mathrm{O}$ by Dick and Zeiske (1998): $D_{x}=2.286 \mathrm{~g} \mathrm{~cm}^{-3}$, which essentially accounts for Na-for$\mathrm{K}$ substitutions that prevail over the $\mathrm{Fe}^{3+}$-for- $\mathrm{Al}$ ones.

A bulk chemical analysis of francoanellite was done by ICP-AES using as starting material a practically monomineralic nodular mass (Sample GDb 11 A) surrounded by clay material. The analysis gave (in wt \%) $\mathrm{K}_{2} \mathrm{O}=6.42$, $\mathrm{Na}_{2} \mathrm{O}=3.19, \quad \mathrm{MnO}=0.03, \quad \mathrm{MgO}=0.05, \quad \mathrm{CaO}=0.09$, $\mathrm{Al}_{2} \mathrm{O}_{3}=19.17, \quad \mathrm{Fe}_{2} \mathrm{O}_{3}=2.11, \quad \mathrm{P}_{2} \mathrm{O}_{5}=45.73$ and $\mathrm{H}_{2} \mathrm{O}$ $($ calculated $)=23.21-$ total 100.00 . All iron was taken as $\mathrm{Fe}^{3+}$. This composition, normalized on the basis of 22 cations in the anhydrous part of the compound and on 13 water molecules, leads to the following chemical-structural formula:

$\left[\mathrm{H}_{6.000} \mathrm{~K}_{1.690} \mathrm{Na}_{1.275} \mathrm{Ca}_{0.020} \mathrm{Mg}_{0.015} \mathrm{Mn}_{0.005}\right]\left(\mathrm{Al}_{4.658} \mathrm{Fe}_{0.327}\right)$ $\left(\mathrm{PO}_{4}\right)_{8.000} \cdot 13 \mathrm{H}_{2} \mathrm{O}$.

Compared with the type material from Castellana Cave, Italy (Balenzano et al., 1976), francoanellite from Gura Dobrogei is richer in both sodium and aluminum, which corroborates the presence of kaolinite and the local abundance of colloidal iron sesquioxides and Na-rich clay material (montmorillonite?) in the terra rossa mass. The structural position normally occupied by $\mathrm{K}^{+}$ions is slightly overcompensated for with a cation sum of 3.005 vs. the ideal 3.00, which indicates that the $\left(\mathrm{NH}_{4}\right)^{+}$-for-K substitution is absent or very limited.

The chemical refractive energy $\left(K_{\mathrm{c}}\right)$ value is 0.2279 and is based on the formula given before and the Gladstone-Dale constants (Mandarino, 1981). The physical refractive energy $\left(K_{\mathrm{p}}\right)$ value, as derived from the average refractive index $(\bar{n})$ 


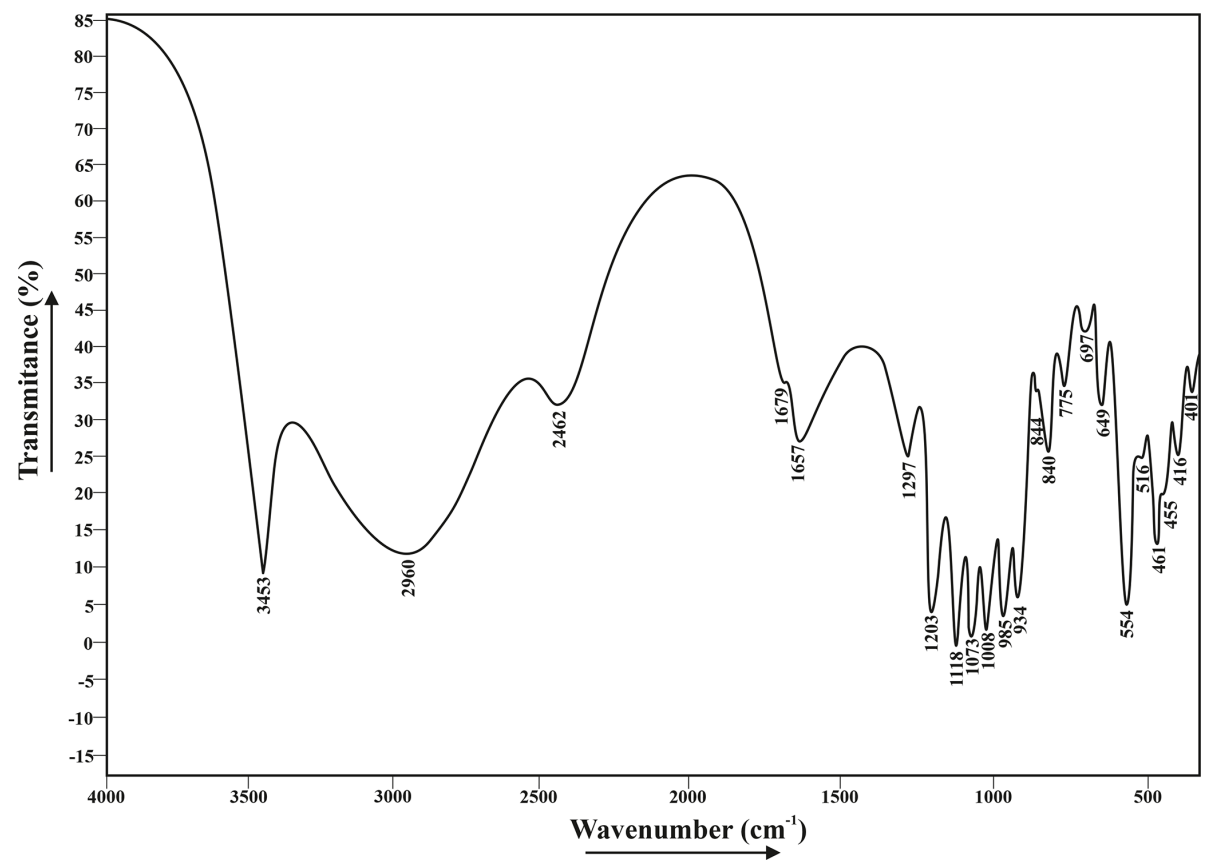

Figure 4. Infrared spectrum of francoanellite from Gura Dobrogei Cave.

and the calculated density is 0.2253 . The physical refractive energy calculated on the basis of the measured density is $K_{\mathrm{p}}^{\prime}=0.2256$. The compatibility index $\left(1-K_{\mathrm{p}} / K_{\mathrm{c}}\right)$ is 0.011 (for $K_{\mathrm{p}}$ ) and 0.010 (for $K_{\mathrm{p}}^{\prime}$ ), which is, in both cases, rated as superior (Mandarino, 1981).

Representative diffraction patterns for the purest francoanellite samples identified at Gura Dobrogei were collected with both $\mathrm{Cu} K \alpha$ and $\mathrm{Fe} K \alpha$ radiation. They are available under request from the first author, and a representative XRD pattern is given in Sect. S1 in the Supplement. The unit cell parameters refined for the two samples (GDb $11 \mathrm{~A}$ and GDb $11 \mathrm{~B}$, respectively) are given in Table 1. They are slightly smaller than the values for $\mathrm{H}_{6} \mathrm{~K}_{3} \mathrm{Al}_{5}\left(\mathrm{PO}_{4}\right)_{8} \cdot 13 \mathrm{H}_{2} \mathrm{O}(a=8.71 \AA, c=82.50 \AA$ according to Smith and Brown, 1959) which could account for limited $\mathrm{Fe}^{3+}$-for-Al replacements. On the other hand, both sets of values compare favorably with the value refined on the basis of X-ray data for the same compound by Dick and Zeiske (1998): $a=8.6897(16) \AA$ and $c=82.271(13) \AA$. The unit cell parameters refined by us are also close to those that can be refined on the basis of the data published for francoanellite from the type locality (Grotte di Castellana, Italy), i.e., $a=8.697(7) \AA$ and $c=82.43(2) \AA$ (as refined on the basis of the two sets of XRD values given by Balenzano et al., 1976), but are slightly smaller than those of francoanellite from Grotta della Rondinella (Italy): $a=8.721(3) \AA$ and $c=82.91(6) \AA$ (as determined on the basis of the three sets of XRD values given by Balenzano et al., 1979).

Figure 4 gives an infrared spectrum of a sample of francoanellite from Gura Dobrogei, whereas Table 2 lists the wavenumbers, characters and intensities of the bands, together with their assignments.

A few comments regarding the spectrum can be made as follows. (1) There is a quite strong resemblance between the infrared spectrum of francoanellite and that of taranakite, based on structural parallelism between the two mineral species (Dick et al., 1998; Dick and Zeiske, 1998). (2) As well as in taranakite (Marincea and Dumitraş, 2003), in the $\mathrm{O}-\mathrm{H}$ stretching region, the infrared absorption spectrum shows one broad and two narrow absorption bands, whose frequency and width indicate hydrogen-bounded O$\mathrm{H}$ stretching vibrations, corresponding to two different positions of the molecular water. In its turn, the H-O-H "scissors" bending of $\mathrm{H}_{2} \mathrm{O}$ is double degenerated (Table 2). (3) No additional vibration band which may be assigned to the $v_{4}$ in-plane bending vibration mode of the $\left(\mathrm{NH}_{4}\right)^{+}$structural group occurs at $\sim 1430 \mathrm{~cm}^{-1}$, indicating the absence of the $\left(\mathrm{NH}_{4}\right)^{+}$-for-K ${ }^{+}$substitutions. (4) As in taranakite, the tetrahedral phosphate anions (part of them protonated) occupy two crystallographic non-equivalent positions, but no signs of polymerization of two protonated phosphate groups according to schema: $2\left(\mathrm{HPO}_{4}\right)^{2-}=\left(\mathrm{H}_{2} \mathrm{PO}_{4}\right)^{-}+\left(\mathrm{PO}_{4}\right)^{3-}$ can be observed, which agrees with the structure resolved by Dick and Zeiske (1998). (5) The antisymmetric stretching of the unprotonated phosphate groups is not double degenerated like in taranakite (Ross, 1974; Marincea and Dumitraş, 2003). 
Table 2. Positions and assumptions of the infrared absorption bands recorded for francoanellite from Gura Dobrogei.

\begin{tabular}{|c|c|c|c|}
\hline Structural group & Vibrational mode & Wavenumber $\left(\mathrm{cm}^{-1}\right)$ & Intensity, character ${ }^{1}$ \\
\hline$\left(\mathrm{HPO}_{4}\right)^{2-}$ & $\mathrm{O}-\mathrm{H}$ stretching & 3453 & $\mathrm{~s}, \mathrm{sh}$ \\
\hline $\mathrm{H}_{2} \mathrm{O}$ & $\mathrm{O}-\mathrm{H}$ stretching & 2960 & $\mathrm{~s}, \mathrm{~b}$ \\
\hline$\left(\mathrm{HPO}_{4}\right)^{2-}$ & $\mathrm{O}-\mathrm{H}$ stretching & 2462 & $\mathrm{~m}, \mathrm{~b}$ \\
\hline $\mathrm{H}_{2} \mathrm{O}$ & $\mathrm{H}-\mathrm{O}-\mathrm{H}$ bending ${ }^{2}$ & 1679 & $\mathrm{~m}$, shd \\
\hline $\mathrm{H}_{2} \mathrm{O}$ & $\mathrm{H}-\mathrm{O}-\mathrm{H}$ bending ${ }^{2}$ & 1657 & $\mathrm{~m}, \mathrm{sh}$ \\
\hline$\left(\mathrm{HPO}_{4}\right)^{2-}$ & $\delta \mathrm{O}-\mathrm{H}$ in-plane bending ${ }^{2}$ & 1297 & $\mathrm{~m}, \mathrm{sh}$ \\
\hline$\left(\mathrm{HPO}_{4}\right)^{2-}$ & $v_{3}, \mathrm{O}-\mathrm{P}-\mathrm{O}$ antisymmetric stretching ${ }^{2}$ & 1203 & $\mathrm{~s}, \mathrm{sh}$ \\
\hline$\left(\mathrm{HPO}_{4}\right)^{2-}$ & $v_{3}$ O-P-O antisymmetric stretching ${ }^{2}$ & 1118 & $\mathrm{~s}, \mathrm{sh}$ \\
\hline$\left(\mathrm{PO}_{4}\right)^{3-}$ & $v_{3}$ O-P-O antisymmetric stretching ${ }^{2}$ & 1073 & s, sh \\
\hline$\left(\mathrm{HPO}_{4}\right)^{2-}$ & $v_{1}$ ' O-P-O symmetric stretching & 1008 & s, sh \\
\hline$\left(\mathrm{HPO}_{4}\right)^{2-}$ & P-O-H symmetric stretching & 985 & s, sh \\
\hline$\left(\mathrm{PO}_{4}\right)^{3-}$ & $v_{1}$ O-P-O symmetric stretching ${ }^{2}$ & 934 & s, sh \\
\hline$\left(\mathrm{HPO}_{4}\right)^{2-}$ & P-O-H symmetric stretching & 844 & $\mathrm{~m}$, shd \\
\hline$\left(\mathrm{HPO}_{4}\right)^{2-}$ & $\delta$ O-H out-of-plane bending & 840 & $\mathrm{~m}, \mathrm{sh}$ \\
\hline$\left(\mathrm{HPO}_{4}\right)^{2-}$ & $\delta \mathrm{O}-\mathrm{H}$ out-of-plane bending & 775 & $\mathrm{w}, \mathrm{sh}$ \\
\hline$\left(\mathrm{HPO}_{4}\right)^{2-}$ & $v_{4}$ ' O-P-O in-plane bending & 697 & $\mathrm{w}, \mathrm{b}$ \\
\hline$\left(\mathrm{HPO}_{4}\right)^{2-}$ & $v_{4} \mathrm{O}-\mathrm{P}-\mathrm{O}$ in-plane bending & 649 & $\mathrm{~m}, \mathrm{sh}$ \\
\hline$\left(\mathrm{PO}_{4}\right)^{3-}$ & $v_{4}$, O-P-O in-plane bending ${ }^{2}$ & 554 & $\mathrm{~s}, \mathrm{sh}$ \\
\hline$\left(\mathrm{PO}_{4}\right)^{3-}$ & $v_{4}$ O-P-O in-plane bending & 516 & $\mathrm{~m}$, shd \\
\hline$\left(\mathrm{AlO}_{6}\right)^{9-}(?)$ & $\mathrm{O}-{ }^{V I} \mathrm{Al}-\mathrm{O}$ stretching & 461 & $\mathrm{~s}, \mathrm{sh}$ \\
\hline$\left(\mathrm{HPO}_{4}\right)^{2-}$ & $v_{2}$ O-P-O out-of-plane bending 2 & 455 & s, shd \\
\hline$\left(\mathrm{PO}_{4}\right)^{3-}$ & $v_{2}$ O-P-O out-of-plane bending ${ }^{2}$ & 416 & $\mathrm{~m}, \mathrm{sh}$ \\
\hline$\left(\mathrm{HPO}_{4}\right)^{2-}(?)$ & $\mathrm{P}-\mathrm{O}-\mathrm{H}$ bending ${ }^{3}$ & 401 & $\mathrm{~m}, \mathrm{sh}$ \\
\hline
\end{tabular}

$1_{\mathrm{s}}=$ strong; $\mathrm{m}=$ medium; $\mathrm{w}=$ weak; $\mathrm{vs}=$ very strong; $\mathrm{sh}=$ sharp; $\mathrm{b}=$ broad; $\mathrm{shd}=$ shoulder ${ }^{2}$ assumptions coincident with those given for taranakite by Arlidge et al. (1963) and Ross $(1974) ;{ }^{3}$ may also represent a $\mathrm{H}_{2} \mathrm{O}$ libration or a lattice mode.

\subsubsection{Monetite}

Monetite was identified in samples containing brushite, and rarely ardealite, as a dehydration product of brushite. Macroscopically, the mineral can not be distinguished properly from the admixed brushite, but its presence was always confirmed by XRD study. The preservation of the samples in sealed plastic bags at room temperature excludes an accidental dehydration. The mixed brushite-monetite samples preserve the snow white macroscopic color of brushite. The SEM study of a monetite-rich aggregate (Sample GDb 5 A) showed groups of platy individual crystals elongated on an indefinite direction of up to $8 \mu \mathrm{m}$ in length and up to $3 \mu \mathrm{m}$ large. Because of the high volatility of the sample under the electron beam, it was impossible to obtain fair-quality microphotographs. It is, however, obvious that the monetite aggregates do not substantially differ from the brushite ones, suggesting that the topotactic substitution of brushite by monetite, following the brushite dehydration, was the principal mechanism of monetite formation.

The crystals of monetite are too small to properly ascertain the refraction indices. For this reason, these were measured by immersion in Cargille oils, as maximum and minimum values, on composite, carefully hand-picked bundles of crystals that show a brushite-like tabular habit. The values obtained were $n_{\max }=1.64$ and $n_{\min }=1.59$, which closely approach those for $\gamma(=1.640-1.65)$ and $\alpha(=1.587-1.60)$, respectively (Palache et al., 1961).

The unit cell parameters refined for three representative samples of monetite on the basis of reflections in the XRD pattern unequivocally attributable to this mineral are given in Table 1, whereas a representative pattern is given in Sect. S1. The structure resolved by Catti et al. (1980) was accepted for refinement. The unit cell parameters are reasonably close to those refined for the stoichiometric monetite: $a=6.90(1) \AA$, $b=6.65(1) \AA, c=7.00(1) \AA, \alpha=96.35^{\circ}, \beta=103.90^{\circ}$ and $\gamma=88.73^{\circ}$ according to MacLennan and Beevers (1955) and $a=6.910(1) \AA, b=6.627(2) \AA, c=6.998(2) \AA, \alpha=$ 96.34(2) ${ }^{\circ}, \beta=103.82(2)^{\circ}$ and $\gamma=88.33(2)^{\circ}$ according to Dickens et al. (1971), respectively. The cell orientation with $c>a>b$ established by refinement (MacLennan and Beevers, 1955; Dickens et al., 1971) is not respected by two but one of the samples in Table 1.

\subsection{Relict minerals in the guano mass}

Quartz, calcite, $2 M 1$ illite and $2 M$ kaolinite were identified as relict minerals in the guano mass. Their description, as well as the crystallographic parameters refined on the basis of XRD patterns, is given in the Supplement (Sect. S2). 


\section{Discussion}

All the "primary" phosphates and sulfates (i.e., hydroxylapatite, brushite, ardealite, taranakite and gypsum) are clearly authigenic, resulting from normal interactions between the pre-existing sediments from the cave floor and walls and the acidic solutions derived from guano. In fact, the biologically driven reactions from the guano mass, and particularly the bacteria-induced ones, ultimately release phosphoric and sulfuric acids (e.g., Forti, 2001; Onac and Forti, 2011). Additional generation of sulfuric acid may have occurred from pyrite or hydrogen sulfide oxidation sourced from green schist formation at the base of the Upper Jurassic limestones contained in the cave. The strongly acidic character of the solutions favors the crystallization of both primary phosphates and sulfates and of the monoclinic polytype of kaolinite (Fialips et al., 2000). The presence of $\left(\mathrm{SO}_{4}\right)^{2-}$ in solution is clearly critical for the formation of gypsum and ardealite.

Taranakite may be interpreted to have been derived through the in situ fixation of potassium and aluminum ions into a phosphate structure (e.g., Sakae and Sudo, 1975). As well as the aluminum, the alkali ions may be available rather from local clay minerals that are susceptible to partial dissolution by the low-pH solution developed from the guano deposit than from distally sourced groundwater. The relicts of illite and kaolinite in the taranakite plus francoanellite mass, as well as the presence of a low crystallinity, semi-colloidal alpha quartz, suggest the decomposition of clay minerals by acidic solutions.

Brushite was probably formed both through replacement of hydroxylapatite and directly by reaction of the acidic solutions derived from the bat guano with calcium carbonate though mechanisms similar to those proposed by Frost and Palmer (2011) or Pak (1981) (see below).

Bassanite, francoanellite and monetite formed during a later stage of guano evolution, typical for the "dry" karst systems, and were found in the driest parts of the cave.

Presumably organic matter from the bat guano dejections, and particularly ammonia, gave locally strong exothermic reactions capable of raising the temperature to up to $100^{\circ} \mathrm{C}$. In fact the reaction of oxidation of ammonia is strongly exothermic (being characterized by a strong negative enthalpy), making it an important local heat source. This reaction can be ideally written as follows:

$4 \mathrm{NH}_{3}(\mathrm{~g})+5 \mathrm{O}_{2}(\mathrm{~g}) \rightarrow 4 \mathrm{NO}(\mathrm{g})+6 \mathrm{H}_{2} \mathrm{O}(\mathrm{g})(\Delta H=$ $\left.-905.2 \mathrm{~kJ} \mathrm{~mol}^{-1}\right)$.

The principal source of ammonia is the urea in the bat droppings. Urea eliminates easier ammonia than hydrolyzes, resulting in quite high local concentrations of $\mathrm{NH}_{3}$ (e.g., Alexandrova and Jorgensen, 2007). Ammonia can also result from reactions similar to that proposed by Frost and Palmer (2011) or Pak (1981) for the formation of brushite from an ammonia-bearing precursor, e.g.,
$\left(\mathrm{NH}_{4}\right)_{2} \mathrm{HPO}_{4}+\mathrm{CaCO}_{3}+\mathrm{H}_{2} \mathrm{O} \rightarrow \mathrm{CaHPO}_{4} \cdot 2 \mathrm{H}_{2} \mathrm{O}+\mathrm{CO}_{2}+$ $2 \mathrm{NH}_{3}$.

Because of the persistence of bat colonies in the cave, layers of fresh guano locally cover the fossil deposits. The decomposition of fresh bat guano by thermochemolysis (Queffelec et al., 2018) releases, even at relatively low temperatures, organic acids, whose reactions with mineral constituents in the cave floor are largely exothermic. On the other side, the low temperature pyrolysis (up to $100^{\circ} \mathrm{C}$ ) of the same material, if present, generates abundant hydrocarbons (Queffelec et al., 2018), whose oxidation is strongly exothermic. The decomposition of the fresh guano consequently generates local "hot" spots or areas that could produce the dehydration of taranakite, gypsum or brushite to produce francoanellite, bassanite or monetite, respectively.

The dynamics of the gypsum-bassanite equilibrium was largely observed in order to explain the topotactic transformation of gypsum into bassanite by natural dehydration, especially in arid environments such as the Sahara Desert (e.g., Mees and Stops, 2003, and references therein). The transition of gypsum into bassanite was generally considered as being due to mere heating at $98^{\circ} \mathrm{C}$ (Posnjak, 1938), but there are indications that this process is also influenced by the pressure, by the presence or absence of a liquid phase, and by the air circulation (Vieillefon, 1978; Smykatz-Closs et al., 1985).

The likely process that leads to the formation of francoanellite is the dehydration of taranakite (Balenzano et al., 1976). Francoanellite was obtained as a breakdown product of taranakite dehydration at temperatures of $105-128^{\circ} \mathrm{C}$ (Marincea and Dumitraş, 2003), but the mineral formation may reflect partial drying of the deposit (Onac and Vereş, 2003) and can occur at lower temperatures. In fact, the formation of francoanellite at the expense of taranakite could be resumed by the loss of interlayer water in taranakite, which is easy to remove. On the other side, in very "dry" systems as at Gura Dobrogei, the primary formation of francoanellite, without taranakite as precursor, can be hypothesized at temperatures up to $100^{\circ} \mathrm{C}$.

In the same line, the complete dehydration of brushite into monetite was obtained at about $220^{\circ} \mathrm{C}$ (Dosen and Giese, 2011), although brushite can be converted into monetite at lower temperatures during prolonged exposure to heat. In fact, monetite can form by equilibration at no more than $37^{\circ} \mathrm{C}$ by attacking powders of tooth enamel with $4 \mathrm{M}$ phosphoric acid and can progressively replace the previously formed brushite (Shellis et al., 1997). On the other hand, ardealite starts to decompose at $125^{\circ} \mathrm{C}$, with all waters of hydration being lost above $226^{\circ} \mathrm{C}$ when the bassanite obtained as a breakdown product loses all water (Frost et al., 2012). It seems reasonable to consider that monetite and bassanite having ardealite as precursor are both stable from $125^{\circ} \mathrm{C}$ or even lower in special conditions. As the dynamics of the ardealite-bassanite equilibrium temperature seems to parallel the gypsum-bassanite equilibrium, a temperature of crys- 
tallization of bassanite plus monetite of up to $100^{\circ} \mathrm{C}$ is more than reasonable.

\section{Conclusions}

Based on the textural relations between the various mineral species, the result is that the chemical and then the thermal transformation of the guano mass at local scale during an early stage of diagenesis was responsible for the structure of the mineral associations in the Gura Dobrogei Cave. The mineral distribution and the local textures suggest that the advance of the reaction front affecting the guano mass was controlled by the general porosity of the sedimentary matrix. The acid solutions that percolated the guano mass may be residual products of microbial degradation that are mostly acids (e.g., Alexander, 1977). The dehydration process of primary guano minerals seems driven by the degradation of organic matter by microbial action and also, presumably, by other exothermic reactions at local scale (e.g., oxidation of ammonia, allogenic pyrite or other organic compounds). In all cases, the breakdown of the organic material is the driving force for authigenic mineral formation.

Data availability. The paper uses GIR data. GIR does not allow for redistribution except for the purpose of replication archives. Permissions can be obtained upon request to the second author.

Supplement. The following materials are available in the Supplement: Sect. S1: representative X-ray powder data for secondary minerals from Gura Dobrogei Cave; Table S1: X-ray powder data for a selected sample of francoanellite from Gura Dobrogei Cave; Table S2: X-ray powder data for a selected sample of monetite from Gura Dobrogei Cave; and Sect. S2: relict minerals in the guano mass (Sect. 4.3.) The supplement related to this article is available online at: https://doi.org/10.5194/ejm-33-329-2021-supplement.

Author contributions. DGD and SM are both responsible for conceptualization, formal analysis, funding acquisition, investigation, data curation, choice of methodologies, and project administration. DGD was responsible for figure drawing. The manuscript was reviewed, visualized and supervised by SM. Both authors have read and agreed to the published version of the manuscript.

Competing interests. The authors declare that they have no conflict of interest.

Acknowledgements. This study was partly supported by a scientific research grant awarded to the first author by the Rhône-Alpes region by means of a MIRA doctoral fellowship granted in 20052006. Part of the analytical support was generously provided by the SPIN Center of Ecole Nationale Supérieure des Mines in Saint-
Etienne, France (ENSMSE), and by the Laboratory of Mineralogy of the University of Liège, Belgium (ULg).

The authors sincerely thank Jacques Moutte (ENSMSE) for kindly supplying the ICP-AES analysis and to Frédéric Hatert (ULg) for assistance in carrying out part of the FTIR analyses. Our late friend, Gabriel Diaconu ("Emil Racoviţă" Speleological Institute in Bucharest), generously provided part of the samples used for the study. Fruitful discussions with André-Mathieu Fransolet, Essaïd Bilal, Maxime Baijot and Frédéric Hatert are highly appreciated. The authors are grateful to five anonymous referees for their thorough reviews of an earlier draft, as well as to Philippe Audra and an anonymous reviewer for the first review of the manuscript. The chief editor Patrick Cordier and the associate editor Cristiano Ferraris generously accepted to review and handle both the initial and the final versions of the manuscript.

Financial support. This research has been supported by the Romanian Ministry of Education and Research and Ministry of Research and Innovation through CNCSIS and UEFISCDI (grants nos. 113/15.10.2001, 4-153/04.11.2004, PN-III-P1-1.2-PCCDI2017-0346 and PN-III-P1-1.1-MC-2018-3163).

Review statement. This paper was edited by Cristiano Ferraris and reviewed by Philippe Audra and one anonymous referee.

\section{References}

Abbona, F., Christenson, F., Franchini Angela, M., and Lundager Madsen, H. E.: Crystal habit and growth conditions of brushite, $\mathrm{CaHPO}_{4} \cdot 2 \mathrm{H}_{2} \mathrm{O}$, J. Cryst. Growth, 131, 331-346, https://doi.org/10.1016/0022-0248(93)90183-W, 1993.

Alexander, M.: Introduction to soil microbiology, 2nd. edn., John Wiley \& Sons Eds., New York, 467 pp., 1977.

Alexandrova, A. N. and Jorgensen, W. L.: Why urea eliminates ammonia rather than hydrolyzes in aqueous solution, J. Phys. Chem., B, 111, 720-730, https://doi.org/10.1021/jp066478s, 2007.

Appleman, D. E. and Evans, H. T.: Indexing and least-squares refinement of powder diffraction data, U.S. Geol. Surv., Comput. Contrib., 20, 60, 1973.

Arlidge, E. Z., Farmer, V. C., Mitchell, B. D., and Mitchell, W. A.: Infra-red, X-ray and thermal analysis of some aluminium and ferric phosphates, J. Appl. Chem., 13, 17-27, https://doi.org/10.1002/jctb.5010130104, 1963.

Audra, P., De Waele, J., Bentaleb, I., Chroňáková, A., Krištůfek, V., D’Angeli, I. M., Carbone, C., Madonia, G., Vattano, M., Scopelliti, G., Cailhol, D., Vanara, N., Temovski, M., Bigot, J.-Y., Nobécourt, J.-C., Galli, E., Rull, F., and Sanz-Aranz, A.: Guano-related phosphate-rich minerals in European caves, Int. J. Speleology, 48, 75-105, https://doi.org/10.5038/1827806X.48.1.2252, 2019.

Balenzano, F., Dell'Anna, L., and Di Pierro, M.: Ricerche mineralogiche su alcuni fosfati rinvenuti nelle grotte di Castellana (Bari): strengite aluminifera, vivianite, taranakite, brushite e idrossiapatite, Rend. Soc. Ital. Miner. Petr., 30, 543-573, 1974. 
Balenzano, F., Dell'Anna, L., and Di Pierro, M.: Francoanellite, $\mathrm{H}_{6} \mathrm{~K}_{3} \mathrm{Al}_{5}\left(\mathrm{PO}_{4}\right)_{8} \cdot 13 \mathrm{H}_{2} \mathrm{O}$, a new mineral from the caves of Castellana, Puglia, southern Italy, N. Jb. Miner. Mh., 2, 49-57, 1976.

Balenzano, F., Dell'Anna, L., and Di Pierro, M.: Francoanellite from the "Grotta della Rondinella" (Litle Swallow cave) in Apulia (Southern Italy): a new occurrence and new data, N. Jb. Miner. Mh., 8, 363-372, 1979.

Ballirano, P., Maras, A., Meloni, S., and Caminiti R.: The monoclinic $I 2$ structure of bassanite, calcium sulphate hemihydrate $\left(\mathrm{CaSO}_{4} \cdot 0.5 \mathrm{H}_{2} \mathrm{O}\right)$, Eur. J. Miner., 13, 985-993, https://doi.org/10.1127/0935-1221/2001/0013/0985, 2001.

Bărbulescu, A.: Late Jurassic bivalvia of Central Dobrogea, Acta Paleontologica Romaniae, 2, 39-51, 1999.

Benoit, P. H.: Adaptation to microcomputer of the ApplemanEvans program for indexing and least-squares refinement of powder-diffraction data for unit-cell dimensions, Am. Mineral., 72, 1018-1019, 1987.

Bigi, A., Falini, G., Foresti, E., Gazzano, M., Ripamonti, A., and Roveri, N.: Rietveld structure refinements of calcium hydroxylapatite containing magnesium, Acta Crystallogr., B52, 87-92, https://doi.org/10.1107/S0108768195008615, 1996.

Brunet, F., Allan, D. R., Redfern, A. T. S., Angel, R. J., Miletich, R., Reichmann, H. J., Sergent, J., and Hanfland, M.: Compressibility and thermal expansivity of synthetic apatites, $\mathrm{Ca}_{5}\left(\mathrm{PO}_{4}\right)_{3} \mathrm{X}$ with $\mathrm{X}=\mathrm{OH}, \mathrm{F}$ and $\mathrm{Cl}$, Eur. J. Mineral., 11, 1023-1035, https://doi.org/10.1127/ejm/11/6/1023, 1999.

Catti, M., Ferraris, G., and Mason, S. A.: Low-temperature ordering of hydrogen atoms in $\mathrm{CaHPO}_{4}$ (monetite): X-ray and neutron diffraction study at $145 \mathrm{~K}$, Acta Crystallogr., 36, 254-259, https://doi.org/10.1107/S0567740880003056, 1980.

Cole, W. F. and Lancucki, C. J.: A refinement of the crystal structure of gypsum, $\mathrm{CaSO}_{4} \cdot 2 \mathrm{H}_{2} \mathrm{O}$, Acta Crystallogr., 30, 921-929, https://doi.org/10.1107/S0567740874004055, 1974.

Curry, N. A. and Jones, D. W.: Crystal structure of brushite, calcium hydrogen orthophosphate dihydrate: a neutron diffraction investigation, J. Chem. Soc., 1971, 3725-3729, https://doi.org/10.1039/j19710003725, 1971.

Dick, S., Gossner, U., Weiss, A., Robl, C., Grossman, G, Ohms, G., and Zeiske, T.: Taranakite - the mineral with the longest crystallographic axis, Inorg. Chim. Acta, 269, 47-57, 1998.

Dick, S. and Zeiske, T.: Francoanellit $\mathrm{K}_{3} \mathrm{Al}_{5}\left(\mathrm{HPO}_{4}\right)_{6} \cdot 12 \mathrm{H}_{2} \mathrm{O}$ : Struktur und Synthese durch topochemische Entwasserung von Taranakit, Z. Naturforsch., 53, 711-719, https://doi.org/10.1515/znb-1998-0711, 1998 (in German with English abstract).

Dickens, B., Bowen, J. S., and Brown, W. E.: A refinement of the crystal structure of $\mathrm{CaHPO}_{4}$ (synthetic monetite), Acta Crystallogr., 28, 797-806, https://doi.org/10.1107/S056774087200322X, 1971.

Dorozhkin, S. V. and Epple, M.: Die biologische und medizinische Bedeutung von Calciumphosphaten, Angew. Chem., 114, 3260-3277, https://doi.org/10.1002/15213757(20020902)114:17<3260::AID-ANGE3260>3.0.CO;2-S, 2002.

Dosen, A. and Giese, R. F.: Thermal decomposition of brushite, $\mathrm{CaHPO}_{4} \cdot 2 \mathrm{H}_{2} \mathrm{O}$ to monetite $\mathrm{CaHPO}_{4}$ and the formation of an amorphous phase, Am. Mineral., 96, 368-373, https://doi.org/10.2138/am.2011.3544, 2011.
Dumitraş, D. G.: A re-investigation of ardealite from the type locality, the "dry" Cioclovina Cave (Şureanu Mountains, Romania), Eur. J. Mineral., 29, 1055-1066, https://doi.org/10.1127/ejm/2017/0029-2655, 2017.

Dumitraş, D. G., Hatert, F., Bilal, E., and Marincea, Ş.: Gypsum and bassanite in the bat guano deposit from the "dry" Cioclovina cave (Sureanu Mountains, Romania), Rom. J. Mineral Dep., 81, 84-87, 2004.

Dumitrescu, M., Tanasachi, J., and Orghidan, T.: The cave from Gura Dobrogei, Anuarul Comitetului Geologic, 31, 461-483, 1958 (in Romanian).

Elliott, J. C.: Structure and chemistry of the apatites and the other calcium orthophosphates, Elsevier, Amsterdam, 404 pp., 1994.

Fialips, C.-I., Petit, S., Decarreau, A., and Beaufort, D.: Influence of synthesis $\mathrm{pH}$ on kaolinite "crystallinity" and surface properties, Clay. Clay Miner., 48, 2, 173-184, https://doi.org/10.1346/CCMN.2000.0480203, 2000.

Forti, P.: Biogenic speleothems: an overview, Int. J. Speleology, 30, 39-56, https://doi.org/10.5038/1827-806X.30.1.4, 2001.

Frost, R. L. and Palmer, S. J.: Thermal stability of the "cave" mineral brushite $\mathrm{CaHPO}_{4} \cdot 2 \mathrm{H}_{2} \mathrm{O}$, Mechanism of formation and decomposition, Thermochim. Acta, 521, 14-17, https://doi.org/10.1016/j.tca.2011.03.035, 2011.

Frost, R. L., Palmer, S. J., and Pogson, R.: Thermal stability of the "cave" mineral ardealite $\mathrm{Ca}_{2}\left(\mathrm{HPO}_{4}\right)\left(\mathrm{SO}_{4}\right) \cdot 4 \mathrm{H}_{2} \mathrm{O}$, J. Therm. Anal. Calorimetry, 107, 549-553, https://doi.org/10.1007/s10973-011-1458-0, 2012.

Giurgiu, A. and Tămaş, T.: Mineralogical data on bat guano deposits from three Romanian caves, Studia UBB, Geologia, 58, 13-18, https://doi.org/10.5038/1937-8602.58.2.2, 2013.

Hill, C. and Forti, P.: Cave minerals of the world, 2nd edn., National Speleological Society, Hunstville, Alabama, 463 pp., 1997.

Karkanas, P., Bar-Yosef, O., Goldberg, P., and Weiner, S.: Diagenesis in prehistoric caves: the use of minerals thatform in situ to assess the completeness of the archaeological record, J. Archaeol. Sci., 27, 915-929, http://https://doi.org/10.1006/jasc.1999.0506, 2000.

Lehr, J. R., Brown, E. H., Frazier, A. W., Smith, J. P., and Thrasher, R. D.: Crystallographic properties of fertilizer compounds, Chem. Eng. Bull. Tenessee Valley Authority, 6, 1-166, 1967.

MacLennan, G. and Beevers, C. A.: The crystal structure of dicalcium phosphate, $\mathrm{CaHPO}_{4}$, Acta Crystallogr., 8, 579-583, https://doi.org/10.1107/S0365110X55001795, 1955.

Mandarino, J. A.: The Gladstone-Dale relationship. I. Derivation of new constants, Can. Mineral., 14, 498-502, 1976.

Mandarino, J. A.: The Gladstone-Dale relationship. IV. The compatibility concept and its application, Can. Mineral., 19, 441-450, 1981.

Marincea, Ş. and Dumitraş, D.: The occurrence of taranakite in the "dry" Cioclovina Cave (Şureanu Mountains, Romania), N. Jb. Miner. Mh., 3, 127-144, https://doi.org/10.1127/00283649/2003/2003-0127, 2003.

Marincea, Ş., Dumitraş, D. G., Diaconu, G., and Fransolet, A.-M.: Mineralogical data on the bat guano deposit from Gura Ponicovei Cave (Almăj Mountains, Romania), Rom. J. Mineral Dep., 81, 126-129, 2004.

McFarlane, D. A. and Lundberg, J.: New records of guanoassociated minerals from caves in northwestern Borneo, 
Int. J. Speleology, 47, 119-126, https://doi.org/10.5038/1827806X.47.2.2169, 2018.

Mees, F. and Stoops, G.: Circumgranular bassanite in a gypsum crust from eastern Algeria - a potential palaeosurface indicator, Sedimentology, 50, 1139-1145, https://doi.org/10.1046/J.13653091.2003.00598, 2003.

Morgan, H., Wilson, R. M., Elliott, J. C., Dowker, S. E. P. and Anderson, P.: Preparation and characterization of monoclinic hydroxyapatite and its precipitated carbonate apatite intermediate, Biomaterials, 21, 617-627, https://doi.org/10.1016/S01429612(99)00225-2, 2000.

Onac, B. P. and Forti, P.: Minerogenetic mechanisms occurring in the cave environment: an overview, Int. J. Speleology, 40, 79-98, https://doi.org/10.5038/1827-806X.40.2.1, 2011.

Onac, B. P. and Vereş, D. Ş.: Sequence of secondary phosphates deposition in a karst environment: evidence from Măgurici Cave (Romania), Eur. J. Mineral., 15, 741-745, http://https://doi.org/10.1127/0935-1221/2003/0015-0741, 2003.

Pak, C. Y. C.: Potential etiologic role of brushite in the formation of calcium (renal) stones, J. Cryst. Growth, 53, 202-208, https://doi.org/10.1016/0022-0248(81)90066-X, 1981.

Palache, C., Berman, H., and Frondel, C. The system of mineralogy II. John Wiley \& Sons Eds., New York, 1124 pp., 1961.

Posnjak, E.: The system $\mathrm{CaSO}_{4}-\mathrm{H}_{2} \mathrm{O}$, Am. J. Sci., 35, 247-272, 1938.

Queffelec, A., Bertran, P., Bos, T., and Lemée, L.: Mineralogical and organic study of bat and chough guano: implications for guano identification in ancient context, J. Cave Karst Studies, 80, 1-17, https://doi.org/10.4311/2017ES0102, 2018.

Ross, S. D.: Phosphates and other oxy-anions of group V, in: The infrared spectra of minerals, edited by: Farmer, V. C., Mineralogical Society Monograph 4, London, 383-422, https://doi.org/10.1180/mono-4.17, 1974.
Sakae, T., Nagata, H., and Sudo, T.: The crystal structure of synthetic calcium phosphate-sulfate hydrate, $\mathrm{Ca}_{2} \mathrm{HPO}_{4} \mathrm{SO}_{4} \cdot 4 \mathrm{H}_{2} \mathrm{O}$ and its relation to brushite and gypsum, Am. Mineral., 63, 520527, 1978.

Sakae, T. and Sudo, T.: Taranakite from the Onino-Iwaya limestone cave at Hiroshima Prefecture, Japan: A new occurrence, Am. Mineral., 60, 331-334, 1975.

Shellis, R. P., Heywood, B. R., and Wahab, F. K.: Formation of brushite, monetite and whitlockite during equilibration of human enamel with acid solutions at $37^{\circ} \mathrm{C}$, Caries Research, 31, 71-77, https://doi.org/10.1159/000262377, 1997.

Simpson, D. R.: The nature of alkali carbonate apatites, Am. Mineral., 49, 363-376, 1964.

Smith, J. P. and Brown, W. E.: X-ray studies of aluminum and iron phosphates containing potassium and ammonium, Am. Mineral., 44, 138-142, 1959.

Smykatz-Closs, W., Istrate, G., and Hötzl, H.: Occurrence and formation of bassanite, $\mathrm{CaSO}_{4} \cdot 1 / 2 \mathrm{H}_{2} \mathrm{O}$, in the gypsum karst area of Foum Tataouine, Southern Tunisia, Chemie der Erde, 44, 6777, 1985.

Van Driesche, A. E. S., Benning, L. G., Rodriguez-Blanco, J. D., Ossorio, M., Bots, P., and Garcia-Ruiz, J. M.: The role and implications of bassanite as a stable precursor phase to gypsum precipitation, Science, 336, 69-72, https://doi.org/10.1126/science.1215648, 2012.

Vieillefon, J.: Etude de l'application des phénomènes de déshydratation et réhydratation du sulfate de calcium à l'estimation des teneurs en eau et en gypse des sols gypseux, O.R.S.T.O.M. Tunisie, E.S.146, 1-36, 1978. 